\title{
Effect of inpatient and outpatient care on treatment outcome in tuberculosis: a cohort study
}

\author{
Marli S. Rocha, ${ }^{1}$ Gisele P. Oliveira, ${ }^{1}$ Valéria Saraceni, ${ }^{2}$ Fernanda P. Aguiar, ${ }^{1}$ \\ Claudia M. Coeli, ${ }^{1}$ and Rejane S. Pinheiro ${ }^{1}$
}

Suggested citation

Rocha MS, Oliveira GP, Saraceni V, Aguiar FP, Coeli CM, Pinheiro RS. Effect of inpatient and outpatient care on treatment outcome in tuberculosis: a cohort study. Rev Panam Salud Publica. 2018;42:e112. https://doi.org/10.26633/RPSP.2018.112

\begin{abstract}
Objective. To identify individual-and health services-related factors associated with deaths in subjects diagnosed with tuberculosis (TB).

Methods. A nonconcurrent cohort study with passive follow-up was conducted using a probabilistic linkage method to analyze a sample of patients diagnosed and reported as having TB in 2006 and followed up until 2008. New cases, cases with previous treatment (readmission after loss to follow-up or relapse), and transfers across health services were included. Proportional hazards models were used to estimate the independent effect of covariates related to the individual and to the health services on mortality from all causes.

Results. Age above 60 years, admission to a hospital with emergency services, HIV-associated $T B$, and readmission to an outpatient facility after disease relapse or loss to follow-up were identified as risk factors for death. Variables related to process and results indicators of Brazil's National TB Program were not associated with mortality from all causes.

Conclusions. Advanced age, previous treatment for TB, and treatment at a secondary-level outpatient facility or a hospital with emergency services on site were associated with mortality in TB patients. Better strategies to improve TB care delivered at health units are needed to prevent death from $T B$, especially among the elderly.
\end{abstract}

Keywords Medical record linkage; mortality; survival analysis; tuberculosis; health service; Brazil.

Brazil ranks 20th among the 30 countries worldwide with a high burden of tuberculosis (TB), with nearly 70000 notified cases and 4400 deaths per year $(1,2)$. Rio de Janeiro had the fourth-highest TB incidence rate of any capital in the country in 2015, and the highest mortality rate in 2014 (2).

Universidade Federal do Rio de Janeiro, RJ, Brazil. Send correspondence to: Marli Souza Rocha, marli. rocha@gmail.com

Secretariat of Health, Rio de Janeiro, RJ, Brazil.
In Brazil, it is recommended that $\mathrm{TB}$ diagnosis and care occur at the primary-level point of entry to health care, with more severe cases referred to hospitals for admission and follow-up $(3,4)$. However, being diagnosed with $\mathrm{TB}$ at an emergency room (ER) is still a common feature, due to access barriers, as reported by Costa et al. (5), who found that more than $50 \%$ of their subjects had been diagnosed at an ER, with 70\% admitted to the hospital.
Mortality is one of the health indicators that reflects the relationship between social and biological issues (6). Studies have shown that individual characteristics such as advanced age, being male, history of TB treatment, alcohol abuse, and mixed or extrapulmonary clinical presentation, as well as the presence of diabetes, HIV, cancer, or other respiratory diseases, may contribute to risk of death from TB. Social conditions such as low educational 
level and poverty also contribute to poor outcomes (7-9).

The type of health care facility where the patient was diagnosed with and/or subsequently treated for TB may be tied to individual characteristics that will influence his/her survival. Patients diagnosed at a hospital or at an ER may differ from those diagnosed at primary care units in terms of access to health care services $(5,10)$.

Operational health indicators may also reflect the quality of care delivered to TB patients (11). Health units with better indicators may have a lower mortality rate for the disease compared to units with worse indicators. This assessment allows for identification of modifiable factors that can reduce or help avert death from TB.

The aim of this study was to identify individual- and health services-related factors associated with deaths in subjects diagnosed with TB.

\section{MATERIALS AND METHODS}

A nonconcurrent cohort study was carried out from 1 January to 31 December 2006 in a population of subjects reported as having TB and living in Rio de Janeiro City. Duplicate entries were identified and removed from the data according to the criteria of the Brazilian Ministry of Health (12). Subjects who were reported as having TB on the same day as their death, or after their death, and people who were incarcerated, were excluded from the analysis.

Patients were passively followed up using probabilistic record linkage combining data for 2006 from the Information System for Notifiable Diseases (Sistema de Informação de Agravos de Notificação, SINAN) and data for 2006-2008 from the Mortality Information System (Sistema de Informações sobre Mortalidade, SIM). SINAN is the national information system developed by the Brazilian Ministry of Health for collecting mandatory disease reporting data and is the main data source for epidemiological surveillance. The World Health Organization (WHO) estimates that $87 \%$ of Brazil's TB cases are reported to the system (13). SIM is the national information system that collects all death certificate data, including cause of death, and has been in place since 1975. In 2012, SIM coverage was $92 \%$ nationwide, and $100 \%$ in 8 states (14).
The open-source software OpenRecLink (15) was used to link the TB surveillance database to the mortality data. Probabilistic record linkage is the combination of data for the same person from two distinct datasets (16). About 6986 TB reports and 118000 death reports were examined. To improve the efficiency of the linkage process, a five-pass blocking strategy was carried out using various indexing keys formed by combining the following fields: name and surname phonetics codes; sex; and year of birth. For each linked record pair, the full name, sex, and date of birth were compared, and a match score was calculated. The final result was the linked records' classification as a "true pair," a "false pair," or a "doubtful pair." Doubtful pairs were sent for clerical revision to determine their final classification (16).

The study outcome was survival time, defined as the number of days between the date of TB diagnosis reported in SINAN and the date of death reported in SIM, up to two years after TB treatment initiation.

Patient independent variables were: 1 ) age ( $<15$ years old, $15-59$ years old, or $60+$ years old); 2) sex; 3) HIV-associated TB ("Yes" or "No"); 4) status at TB treatment entry (new case or unknown; readmission due to disease relapse, or after loss to follow-up; or transfer from other health services); and 5) clinical presentation. A stratified analysis was carried out by dividing the patients into four groups by the type of health care facility where they were diagnosed (outpatient facility or hospital) and HIV status (positive or negative).

The variables (indicators) for each outpatient clinic were: 1 ) proportion of cases with treatment completion, 2) proportion of cases lost to follow-up, 3) proportion of cases that had no information on the TB treatment outcome, 4) proportion of cases for which a sputum smear microscopy was carried out, 5) proportion of cases tested for HIV, and 6) level of health care provided (primary or secondary). These variables were categorized according to parameters provided by the National TB Program, and the spline function was used to investigate other cutoff points of possible interest.

The variables (indicators) for hospitals were: 1) type (general or infectious diseases facility); 2) administrative level/ legal status (municipal, state, federal, charity/private, or university hospital); and 3) having an emergency room on site ("Yes" or "No").

Data were examined using the Kaplan-Meier method and differences in survival curves were tested using the log-rank test. A full survival model that included the significant variables from simpler models was further developed using a hierarchical design consisting of distal, intermediate, and proximal variables (11). Variables at the same hierarchical level were added to the model, beginning with the distal level (variables related to health facilities), and moving up to the proximal level (variables related to individuals / patients); those that did not show statistical significance at $\alpha=0.10$ were excluded from the model. Every time a nonsignificant variable was excluded, the coefficients of the models with and without the variable were compared to evaluate the need to maintain the variable in the adjusted model. The final model included variables with $P<0.05$ when adjusted for variables at the same and higher levels.

The association between independent covariates and time to death was assessed using the hazard ratio with a $95 \%$ confidence interval (CI). The proportionality of hazards and the quality of the adjustment were investigated using the Schoenfeld residuals.

Analyses were performed using the survival library from the open-source $\mathrm{R}$ statistical package (version 2.15.3) (R Foundation for Statistical Computing, Vienna, Austria; www.r-project.org).

The study was approved by the Research Ethics Committee of the Institute for Studies in Collective Health at the Federal University of Rio de Janeiro (UFRJ), protocol \#180.005/2012. Because this was a retrospective study based on routine program information, informed consent was not obtained. All data were kept strictly confidential to ensure anonymity.

\section{RESULTS}

In 2006, 6986 TB cases were registered in SINAN as new TB cases or retreatment. Of those cases for 2006, 26 were not diagnosed with TB until their death and were thus excluded from the sample pool to avoid violation of the proportionality assumption; most of these 26 excluded cases were male $(73.1 \%), 15-59$ years old $(77.0 \%)$, and seen at hospitals (80.8\%). A total of 74 cases whose diagnoses were 
modified after notification, 459 people who were incarcerated, and 83 duplicate records were also excluded.

The final study cohort comprised 6 344 individuals; about two-thirds were male and most (about $80 \%$ ) entered the health facility for TB treatment as new cases. A total of $11.3 \%$ had HIV-associated TB, and $799(12.6 \%)$ had died at the time of the analysis (Table 1 ).

Of the 6344 individuals, 1368 (21.6\%) were admitted to hospitals (Table 1). About one-third of these were diagnosed with TB at hospitals with a municipal administrative level / legal status. With regard to type of hospital, about one-third was diagnosed at infectious diseases hospitals (versus general hospitals). About $40 \%$ of the admitted patients were at hospitals with emergency services. The remaining 4976 individuals (78.4\% of the cohort) were diagnosed at outpatient facilities-mostly primary care (Table 1).

Most individuals were followed up at outpatient facilities (versus hospitals). The large majority of them were seen at facilities that reported TB treatment completion rates $<85 \%,>5 \%$ of TB cases lost to follow-up, and TB case HIV testing rates $<60 \%$. About half were seen at outpatient facilities that reported giving less than $80 \%$ of TB patients a sputum smear microscopy. A small proportion (5.7\%) were seen at facilities reporting that for more than $15 \%$ of TB patients there was no information about the TB treatment outcome (Table 1).

Among subjects without HIV-associated TB who were diagnosed at outpatient clinics, the risk of death was higher in those 1) older than 60 years (adjusted hazard ratio $(\mathrm{aHR})=3.8,95 \%$ CI 2.1-6.8); 2) readmitted to a health care facility due to disease relapse $(\mathrm{aHR}=2.2, \mathrm{CI} 1.1-4.4)$, or after being temporarily lost to follow-up (aHR = 2.8, CI 1.3-5.8); and 3) followed up at a secondary care clinic $(\mathrm{aHR}=1.7$, CI 1.0-3.0) (Table 2). Among HIV-positive cases followed up at outpatient clinics, no statistical difference was noted regarding care.

For subjects without HIV-associated TB who were diagnosed at hospitals, the risk of death was higher in those 1) older than 60 years $(\mathrm{aHR}=1.9, \mathrm{CI} 1.1-3.3)$ and 2) diagnosed at a hospital with an ER on site (aHR = 2.8, CI 1.8-4.6) (Table 3). The HIV-infected subjects who were diagnosed with $\mathrm{TB}$ at hospitals had a higher risk of death if 1) they were older
TABLE 1. Characteristics of cohort subjects and health units in study of the effect of inpatient/outpatient care on tuberculosis (TB) treatment outcome, Rio de Janeiro, Brazil, 2006-2008

\begin{tabular}{|c|c|c|c|c|}
\hline \multirow{2}{*}{ Variable } & \multicolumn{2}{|c|}{ Total } & \multicolumn{2}{|c|}{ Deaths } \\
\hline & No. & $\%$ & No. & $\%$ \\
\hline Individuals $(n=6344)$ & & & 799 & 12.6 \\
\hline \multicolumn{5}{|l|}{ Sex } \\
\hline Female & 2277 & 35.9 & 251 & 11.0 \\
\hline Male & 4067 & 64.1 & 548 & 13.5 \\
\hline \multicolumn{5}{|l|}{ Age (years) } \\
\hline$<15$ & 233 & 3.7 & 9 & 3.9 \\
\hline $15-59$ & 5388 & 84.9 & 594 & 11.0 \\
\hline$\geq 60$ & 714 & 11.3 & 196 & 27.5 \\
\hline \multicolumn{5}{|l|}{ Clinical presentation } \\
\hline Pulmonary & 5100 & 80.4 & 605 & 11.9 \\
\hline Extrapulmonary & 941 & 14.8 & 127 & 13.5 \\
\hline Mixed & 303 & 4.8 & 67 & 22.1 \\
\hline \multicolumn{5}{|l|}{ Status at TB treatment entry } \\
\hline New case + unknown & 5265 & 83.0 & 614 & 11.7 \\
\hline Relapse & 459 & 7.2 & 74 & 16.1 \\
\hline Readmission after loss to follow-up & 432 & 6.8 & 71 & 16.4 \\
\hline Transfer & 188 & 3.0 & 40 & 21.3 \\
\hline \multicolumn{5}{|l|}{ HIV-associated TB } \\
\hline Yes & 717 & 11.3 & 214 & 29.8 \\
\hline No & 1934 & 30.5 & 143 & 7.4 \\
\hline No information available & 3693 & 58.2 & 442 & 12.0 \\
\hline Hospitals $(n=1368)^{\mathrm{a}}$ & & & 335 & 24.5 \\
\hline \multicolumn{5}{|l|}{ Administrative level / legal status ${ }^{a}$} \\
\hline Municipal & 450 & 33.8 & 126 & 28.0 \\
\hline State & 202 & 15.2 & 66 & 32.7 \\
\hline Federal & 303 & 22.7 & 70 & 23.1 \\
\hline Charity / private & 39 & 2.9 & 15 & 38.5 \\
\hline University hospital & 339 & 25.4 & 54 & 15.9 \\
\hline \multicolumn{5}{|l|}{ Type $^{\mathrm{a}}$} \\
\hline General & 914 & 68.6 & 248 & 27.1 \\
\hline Infectious diseases & 419 & 31.4 & 83 & 19.8 \\
\hline \multicolumn{5}{|l|}{ Emergency room available ${ }^{a}$} \\
\hline No & 817 & 61.3 & 129 & 15.8 \\
\hline Yes & 516 & 38.7 & 202 & 39.1 \\
\hline Outpatient facilities ( $n=4976$ ) & & & 464 & 9.3 \\
\hline Primary care & 4170 & 83.8 & 379 & 9.1 \\
\hline Secondary care & 806 & 16.2 & 85 & 10.5 \\
\hline \multicolumn{5}{|l|}{$\%$ treatment completed } \\
\hline $0-84$ & 4893 & 77.1 & 461 & 9.4 \\
\hline$\geq 85$ & 83 & 21.3 & 3 & 3.6 \\
\hline \multicolumn{5}{|l|}{$\%$ of cases lost to follow-up } \\
\hline $0-5$ & 114 & 2.3 & 5 & 4.4 \\
\hline $6-10$ & 656 & 13.2 & 47 & 7.2 \\
\hline $11-20$ & 3038 & 61.0 & 290 & 9.5 \\
\hline $21-100$ & 1168 & 23.5 & 122 & 10.4 \\
\hline \multicolumn{5}{|l|}{$\%$ of TB cases tested for HIV } \\
\hline $0-60$ & 3381 & 67.9 & 343 & 10.1 \\
\hline $61-100$ & 1595 & 32.1 & 121 & 7.6 \\
\hline \multicolumn{5}{|c|}{$\%$ of cases with a sputum smear microscopy performed } \\
\hline $0-79$ & 2308 & 46.4 & 219 & 9.5 \\
\hline $80-89$ & 1921 & 38.6 & 197 & 10.3 \\
\hline $90-100$ & 747 & 15.0 & 48 & 6.4 \\
\hline \multicolumn{5}{|l|}{$\%$ of cases with missing treatment outcome } \\
\hline $0-14$ & 4692 & 94.3 & 446 & 9.5 \\
\hline $15-100$ & 284 & 5.7 & 18 & 6.3 \\
\hline
\end{tabular}

Source: Prepared by the authors based on the study results.

aThere were 35 records (including four deaths) with missing values for hospital-related variables. 
TABLE 2. Cox regression model for deaths in individuals with and without HIV-associated tuberculosis (TB) followed up at outpatient facilities, Rio de Janeiro, Brazil, 2006-2008

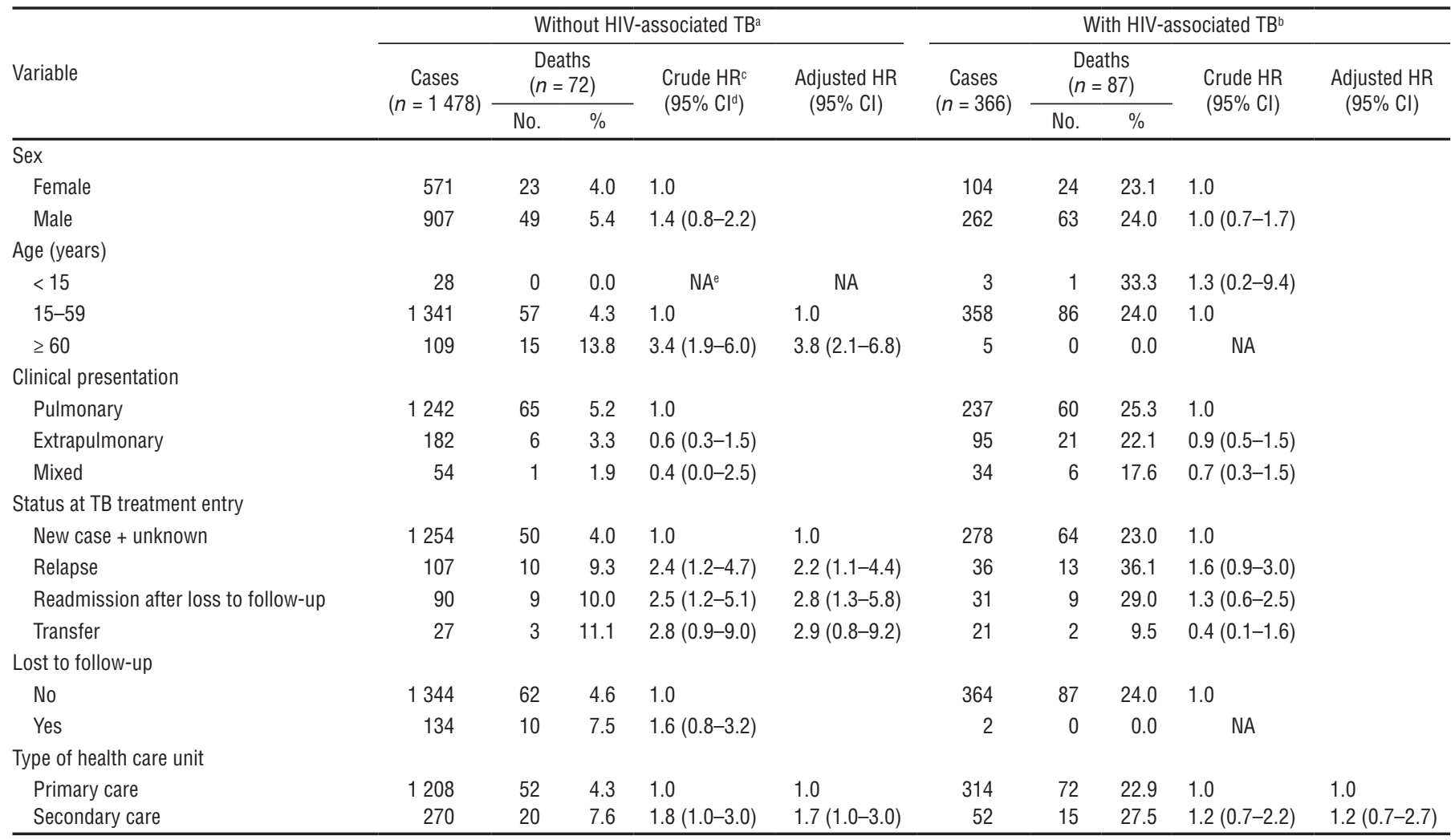

Source: Prepared by the authors based on the study results.

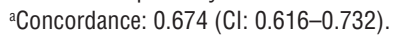

${ }^{\mathrm{b}} \mathrm{Concordance:} 0.52$ (Cl: 0.48-0.56).

cHR: hazard ratio.

${ }^{\mathrm{d}} \mathrm{Cl}$ : confidence interval.

${ }^{e N A}$ : not applicable.

than 60 years $(\mathrm{aHR}=3.0, \mathrm{CI} 1.4-6.4)$ or 2$)$ the hospital had an ER on site $(\mathrm{aHR}=2.7$, CI 1.9-3.8) (Table 3).

\section{DISCUSSION}

It was observed that factors associated with survival in the group of patients followed up at outpatient clinics differed from those associated with this same outcome in patients admitted to hospitals, a difference that was also observed between groups with and without HIV-associated TB.

Patients with advanced age, and those who had been treated for TB previously, and treatment at a secondary-level outpatient clinic, and at hospitals with ERs on site, were associated with patient survival.

Advanced age was strongly associated with mortality from TB and could be a confounder acting on the association of other variables with the outcome. The higher risk of death in elderly people may be related to reduced immunity and/or the increased difficulty in diagnosing TB in older people, because they are more likely to have nonspecific symptoms, which delays the start of treatment (17). In addition, mortality may be related to the presence of comorbidities, unfavorable living conditions, malnutrition, and difficulties in accessing health services $(18,19)$. In Brazil, TB is more common among young adults and is not considered a typical disease of the elderly. Given the diagnostic difficulties in older people, the clinical hypothesis of TB in older age groups must be considered and better investigated $(20,21)$.

In individuals without HIV-associated TB who were followed up in outpatient clinics, death was associated with a history of 1) previous TB treatment; 2) being seen at the secondary level; and
3) comorbidities most likely requiring a more complex approach to the disease. Directly Observed Therapy (DOT) has been cited as an effective strategy for these patients, as treatment adherence is one of the most important aspects of TB control (4). Currently, with broader coverage of the Family Health Program in Brazilian health care facilities, coverage with DOT, or Directly Observed Treatment, Short Course (DOTS) is expected to increase considerably (22).

Resistance to $\mathrm{TB}$ drugs can increase mortality to the disease $(23,24)$. In Brazil, patients with drug resistance are monitored in another (non-SINAN) information system, so their TB treatment outcome is eliminated from the main (SINAN) database, where they are then classified as "TB-drug resistant (TB-DR)" cases. During the study period, the results of the drug sensitivity test were not registered in SINAN. Therefore, some 
TABLE 3. Cox regression model for deaths in individuals with and without HIV-associated tuberculosis (TB) admitted at hospitals, Rio de Janeiro, Brazil, 2006-2008

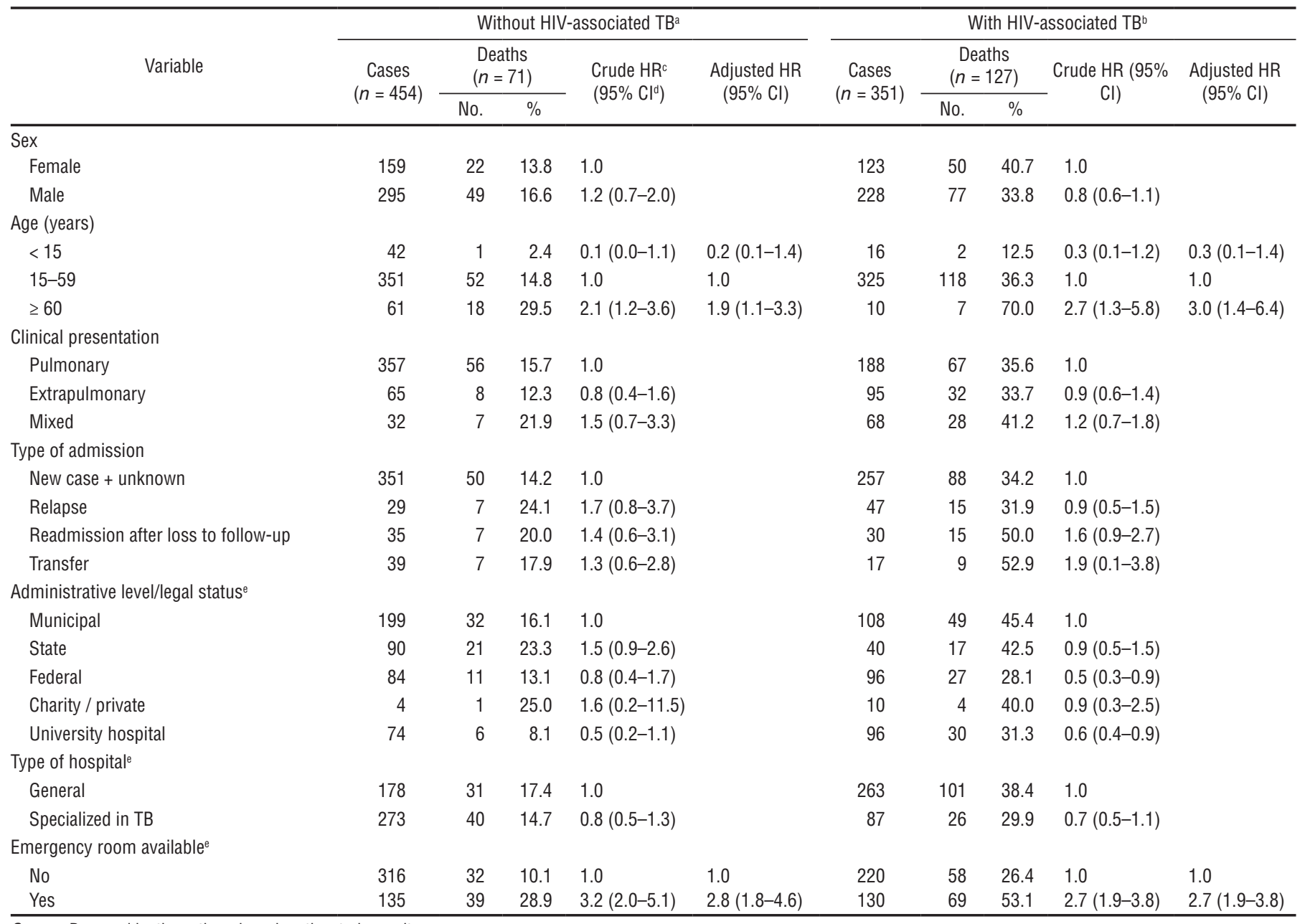

Source: Prepared by the authors based on the study results.

aConcordance: 0.679 (Cl: $0.617-0.741$ ).

boncordance: 0.651 (Cl: $0.607-0.695)$.

cHR: hazard ratio.

${ }^{\circ} \mathrm{Cl}$ : confidence interval.

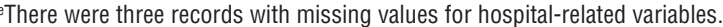

cases reported as deaths in this study may have been TB-DR cases.

For individuals with HIV-associated TB who were followed up at outpatient clinics, the severity of a particular health status was more relevant to survival, given that, if they were being seen at outpatient facilities, no association with important predictors for TB, such as age, was found in their record. HIV/AIDS alone has a strong impact on mortality in TB patients because it hinders early diagnosis, changes the classic presentation of the chest $x$-ray, and increases the probability of both relapse (25) and loss to follow-up, due to treatment side effects (26-28).
Of the operational indicators related to TB care at outpatient clinics, none was found to be associated with survival, which suggests that the organization of a health program does not have an effect on mortality from all causes. Although these indicators could not explain mortality, they may be important in explaining treatment adherence, a crucial factor for TB cure. One hypothesis would be that the severity of the case could be related to other comorbidities, or to delays in diagnosis and/or treatment $(7,18,19,23)$. Admission to a hospital with an ER on site was a highly relevant risk predictor for death, suggesting there can be barriers to accessing care and to adequate and timely treatment at the outpatient clinics, as would be expected due to certain limitations at these facilities versus hospitals. The start of treatment could therefore be delayed, possibly leading to a more severe case of TB, which, in turn, would increase the chance of complications that could affect mortality (29).

This analysis did not include certain health care service variables that could be related to outpatient facilities, and could affect TB treatment outcome, such as 1) delays in diagnosis and treatment that could result from limited business hours at these facilities; 2) difficulties in performing high-complexity tests at these facilities to confirm diagnosis, or services 
being located far from patients' homes; 3 ) barriers to accessing care for complications arising during treatment at these facilities $(10,30)$; and 4) limited experience of some outpatient staff in clinical diagnosis, especially in the absence of classic symptoms of the disease, or in the presence of comorbidities, such as HIV / AIDS and diabetes $(5,31)$. Further studies are needed to test those hypotheses.

There was a high frequency of individuals without HIV-associated TB admitted to hospitals with emergency services, reinforcing the hypothesis described above. Nonetheless, it is possible that admission to a hospital with emergency services could be an indicator of severity. In a study that analyzed factors related to the delay in seeking health care and diagnosis in metropolitan Rio de Janeiro, Costa et al. (5) found that $84 \%$ of individuals with TB admitted to hospitals were admitted through an ER. Of those who were diagnosed at the time of admission, $79.7 \%$ remained hospitalized at the emergency facility or were transferred to another hospital.

In individuals with HIV/AIDS, admission to a hospital with emergency services suggests that the disease had not been previously diagnosed or that there were complications in the treatment for HIV/AIDS. Reference hospitals for the treatment of HIV / AIDS, such as federal and university hospitals, would certainly have treated these patients when they were affected by TB.

The results of this study warrant a deeper investigation of the reasons behind the suggested predictors, such as barriers to accessing timely diagnosis and, thus, appropriate and timely TB treatment. The number of cases starting treatment at emergency services, and with short survival, pointed to the possibility of delay in diagnosis and treatment initiation. The association between advanced age and risk of death may reinforce this hypothesis, given the difficulty in establishing TB diagnosis in elderly people, due to the presence of comorbidities and overlapping symptoms from other diseases that are common in this age group.

TB-related death is an avoidable event that deserves a thorough investigation to identify its causes, especially those that can be addressed by creating new strategies at the health services level. Health care personnel should be more aware of subjects with severity predictors, such as older people, who deserve more attention.

\section{Limitations}

One limitation of this study was the quality of the data (routine data from national databases). Errors in the record linkage process were another potential

\section{REFERENCES}

1. World Health Organization. Use of high burden country lists for TB by WHO in the post-2015 era. Geneva: WHO; 2016.

2. Ministério da Saúde, Secretaria de Vigilância em Saúde (BR). Perspectivas brasileiras para o fim da tuberculose como problema de saúde pública. Bol Epidemiológico. 2016;47(13):1-15. Available from: http:// portalarquivos.saude.gov.br/images / pdf/2016/marco/24/2016-009-Tuberculose-001.pdf

3. Ministério da Saúde, Secretaria de Atenção à Saúde, Departamento de Atenção Básica (BR). Política Nacional de Atenção Básica. Brasília: MS; 2012. Available from: http:/ / dab.saude.gov.br/portaldab/biblioteca. php? conteudo=publicacoes $/$ pnab

4. Ministério da Saúde, Secretaria de Vigilância em Saúde, Departamento de Vigilância Epidemiológica (BR). Manual de recomendações para o controle da tuberculose no Brasil. Brasília: MS; 2011. Available from: http://bvsms.saude.gov.br/bvs/ publicacoes/manual_recomendacoes_controle_tuberculose_brasil.pdf

5. Costa PV, Senna AL, Oliveira LG, Siqueira RC, Figueiredo SP. Demora no diagnóstico da tuberculose pulmonar em cinco municípios da região metropolitana do Rio de Janeiro, Brasil, 2009-2010. Cad Saude Colet (Rio J.). 2012;20(2):195-202.

6. Vicentin G, Santo AH, Carvalho MS. Mortalidade por tuberculose e indicadores sociais no município do Rio de Janeiro. Cien Saude Colet. 2002;7(2):253-63. doi: 10.1590/S1413-81232002000200006.

7. de Albuquerque MdeF, Ximenes RA, Lucena-Silva N, de Souza WV, Dantas AT, Dantas OM, et al. Factors associated with treatment failure, dropout, and death in a cohort of tuberculosis patients in Recife, Pernambuco State, Brazil. Cad Saude Publica. 2007;23(7):1573-82. doi. org/10.1590/S0102-311X2007000700008.

8. Bernabé-Ortiz A. Factores asociados a supervivencia en pacientes con tuberculosis en Lima, Perú. Rev Chilena Infectol. 2008;25(2):104-7. doi: /S0716-10182008000 300002.

9. Sassaki CM, Scatena LM, Gonzales RI, Ruffino-Netto A, Hinos P, Villa TC. Predictors of favorable results in pulmonary tuberculosis treatment (Recife, Pernambuco, Brazil, 2001-2004). Rev Esc limitation but would not introduce bias in the model coefficients as long as no doubtful pair was deemed to be a case of death in the clerical review (15).

\section{Conclusions}

Strategies focusing on an earlier diagnosis of TB are warranted, especially among the elderly, as this age group had a higher risk of death from the disease. In addition, it is important to reinforce the role of primary care in the prevention, detection, diagnosis, treatment, and monitoring of TB cases.

Funding. This work was supported by the National Council for Scientific and Technological Development (CNPq) and the Carlos Chagas Filho Foundation for Research Support of the State of Rio de Janeiro (FAPERJ), and by a scholarship from the Coordination for the Improvement of Higher Education Personnel (CAPES).

\section{Conflicts of interests. None.}

Disclaimer. Authors hold sole responsibility for the views expressed in the manuscript, which may not necessarily reflect the opinion or policy of the RPSP/ PAJPH or the Pan American Health Organization (PAHO).
Enferm USP. 2010;44(2):504-10. doi: 10.1590/S0080-62342010000200037.

10. Oliveira MF, Villa TC, Arcêncio RA, Scatena LM, Ruffino-Netto A. O acesso ao diagnóstico da TB nos serviços de saúde do município Ribeirão Preto - SP (2007). In: Villa TC, Ruffino-Netto A, editors. Tuberculose: pesquisas operacionais. Ribeirão Preto, SP: FUNPEC-Editora; 2009. Pp. 36-42. Available from: http://www.eerp.usp.br/ geotb/Doc/Tuberculose.pdf

11. Victora CG, Huttly SR, Fuchs SC, Olinto MT. The role of conceptual frameworks in epidemiological analysis: a hierarchical approach. Int J Epidemiol. 1997;26(1):224-7. doi: 10.1093/ije/26.1.224.

12. Ministério da Saúde, Secretaria de Vigilância em Saúde, Departamento de Vigilância Epidemiológica (BR). Sistema de Informação de Agravos de Notificação - Sinan: normas e rotinas. 2nd ed. Brasília: MS; 2007. Available from: http://bvsms.saude.gov. br/bvs/publicacoes/07_0098_M.pdf

13. World Health Organization. Global tuberculosis report 2017. Geneva: WHO; 2017. Available from: http:/ / www.who.int/tb / publications/global_report/en/ 
14. Ministério da Saúde, Secretaria de Vigilância em Saúde, Departamento de Vigilância de Doenças e Agravos Não Transmissíveis e Promoção da Saúde (BR). Saúde Brasil 2014: uma análise da situação de saúde e das causas externas. Brasília: MS; 2015. Available from: http://bvsms.saude.gov. br/bvs/publicacoes/saude_brasil_2014_ analise_situacao.pdf

15. Camargo KR Jr, Coeli CM. Going open source: some lessons learned from the development of OpenRecLink. Cad Saude Publica. 2015;31(2):257-63. doi: 10.1590/ 0102-311X00041214.

16. Coeli CM, Pinheiro RS, Camargo KR Jr. Achievements and challenges for employing record linkage techniques in health research and evaluation in Brazil. Epidemiol Serv Saude. 2015;24(4): 795-802. doi: 10.5123/S1679-49742015000 400023.

17. Negin J, Abimbola S, Marais BJ. Tuberculosis among older adults - time to take notice. Int J Infect Dis. 2015;32:135-7. doi: 10.1016/ j.ijid.2014.11.018.

18. Lee J, Nam HW, Choi SH, Yoo SS, Lee SY, Cha SI, et al. Comparison of early and late tuberculosis deaths in Korea. J Korean Med Sci. 2017;32(4):700-3. doi: 10.3346/ jkms.2017.32.4.700.

19. Sousa LM, Pinheiro RS. Unnotified deaths and hospital admissions for tuberculosis in the municipality of Rio de Janeiro. Rev Saude Publica. 2011;45(1):31-9. doi. org/10.1590/S0034-89102011000100004.

20. Lin YS, Yen YF. Determinants of mortality before start of and during tuberculosis treatment among elderly patients: a population-based retrospective cohort study. Age Ageing. 2015;44(3):490-6. doi: 10.1093/ ageing/afv002.
21. Shen X, DeRiemer K, Yuan Z, Shen M, Xia $Z$, Gui X, et al. Deaths among tuberculosis cases in Shanghai, China: who is at risk? BMC Infect Dis. 2009;9:95. doi: 10.1186/ 1471-2334-9-95.

22. Prado JC Jr, Virgilio TC, Medronho R de A. Cure rates for tuberculosis in the municipality of Rio de Janeiro, Brazil, in 2012 compared with coverage by, and time of establishment of, Family Health units, and socio-economic and demographic factors. Cien Saude Colet. 2016;21(5):1491-8. doi: 10.1590/1413-81232015215.03912016.

23. Adamu AL, Gadanya MA, Abubakar IS, Jibo AM, Bello MM, Gajida AU, et al. High mortality among tuberculosis patients on treatment in Nigeria: a retrospective cohort study. BMC Infect Dis, 2017;17(1):170. doi: 10.1186/s12879-017-2249-4.

24. Mathew TA, Ovsyanikova TN, Shin SS Gelmanova I, Balbuena DA, Atwood S, et al. Causes of death during tuberculosis treatment in Tomsk Oblast, Russia. Int J Tuberc Lung Dis. 2006;10(8):857-63.

25. Adejumo OA, Daniel OJ, Otesanya AF, Adegbola AA, Femi-Adebayo T, Bowale A, et al. Factors associated with TB/HIV co-infection among drug sensitive tuberculosis patients managed in a secondary health facility in Lagos, Nigeria. Afr J Infect Dis. 2017;11(2):75-82. doi: 10.21010/ ajid.v11i2.10

26. Michael OS, Sogaolu OM, Fehintola FA, Ige OM, Falade CO. Adverse events to first line anti-tuberculosis drugs in patients co-infected with HIV and tuberculosis. Ann Ib Postgrad Med. 2016;14(1):21-9. PMID: 27721682.

27. Campani ST, Moreira Jda S, Tietbohel CN. Pulmonary tuberculosis treatment regimen recommended by the Brazilian National
Ministry of Health: predictors of treatment noncompliance in the city of Porto Alegre, Brazil. J Bras Pneumol. 2011;37(6):776-82. doi.org/10.1590/S1806-37132011000600011.

28. Gebremariam MK, Bjune GA, Frich JC. Barriers and facilitators of adherence to $\mathrm{TB}$ treatment in patients on concomitant TB and HIV treatment: a qualitative study. BMC Public Health. 2010;10:651. doi 10.1186/1471-2458-10-651.

29. Rodrigo T, Casals M, Caminero JA, GarcíaGarcía JM, Jiménez-Fuentes MA, Medina JF, et al. Factors associated with fatality during the intensive phase of anti-tuberculosis treatment. PLoS ONE. 2016;11(8):e0159925. doi: 10.1371/journal.pone.0159925.

30. Arakawa T, Villa TC, Arcêncio RA, Cardozo-Gonzales RI, Scatena LM, RuffinoNeto A. A acessibilidade de doentes de tuberculose ao tratamento em serviços de saúde no município de Ribeirão Preto - São Paulo (2006-2007). In: Villa TC, RuffinoNetto A, editors. Tuberculose: pesquisas operacionais. Ribeirão Preto, SP: FUNPECEditora; 2009. Pp. 48-55. Available from: http:/ / www.eerp.usp.br/geotb /Doc/ Tuberculose.pdf

31. Machado AC, Steffen RE, Oxlade O, Menzies D, Kritski A, Trajman A. Factors associated with delayed diagnosis of pulmonary tuberculosis in the state of Rio de Janeiro, Brazil. J Bras Pneumol. 2011;37(4):512-20. doi: 10.1590/S1806-37132011000400014.

Manuscript submitted 8 November 2017. Revised version accepted for publication on 10 May 2018. 
RESUMEN Objetivo. Identificar los factores individuales y los factores relacionados con los servicios de salud asociados con la muerte de personas con diagnóstico de tuberculosis.

Métodos. Se realizó un estudio de cohortes no concurrentes con seguimiento pasivo,

Efecto de la atención hospitalaria y ambulatoria en el resultado del tratamiento de la tuberculosis: un estudio de cohortes

Palabras clave con un método de nexo probabilístico, para analizar una muestra de pacientes a quienes se les diagnosticó tuberculosis y se notificaron sus casos en el 2006, y se les dio seguimiento hasta el 2008. Se incluyeron casos nuevos, casos con tratamiento anterior (reingreso después de haber abandonado el seguimiento o por recaída) y transferencias entre distintos servicios de salud. Se usaron modelos de riesgos proporcionales para calcular el efecto independiente de las covariables relacionadas con los individuos y con los servicios de salud en la mortalidad por todas las causas.

Resultados. Se determinó que los factores de riesgo de muerte son: edad mayor de 60 años, ingreso a un hospital con servicios de urgencia, tuberculosis asociada con la infección por el VIH y reingreso a un establecimiento de atención ambulatoria después de la recaída de la enfermedad o de abandonar el seguimiento. Las variables relacionadas con los procesos y los indicadores de resultados del Programa Nacional contra la Tuberculosis de Brasil no se asociaron con la mortalidad por todas las causas. Conclusiones. La edad avanzada, el antecedente de tratamiento antituberculoso y el tratamiento en un establecimiento ambulatorio de nivel secundario o un hospital con servicios integrados de urgencia se asociaron con la mortalidad de los pacientes con tuberculosis. Se necesitan mejores estrategias para optimizar los servicios de atención de la tuberculosis que prestan las unidades de salud a fin de evitar la muerte por esta enfermedad, especialmente en las personas de mayor edad.

Registro médico coordinado; mortalidad; análisis de supervivencia; tuberculosis; servicios de salud; Brasil.

RESUMO

\section{Efeito da atenção hospitalar e ambulatorial sobre $o$ desfecho do tratamento da tuberculose: estudo de coorte}

Palavras-chave
Objetivo. Identificar fatores individuais e relacionados aos serviços de saúde associados com mortalidade em indivíduos com diagnóstico de tuberculose (TB).

Métodos. Estudo longitudinal não concorrente de seguimento passivo por método de linkage probabilístico, realizado em uma amostra de pacientes diagnosticados e notificados com TB em 2006 e seguidos até 2008. Casos novos, com histórico de tratamento anterior (readmitidos após perda de seguimento ou recorrência) ou transmitidos entre diferentes serviços de saúde foram incluídos. Modelos de riscos proporcionais foram utilizados para estimar o efeito independente de covariáveis do indivíduo e do serviço de saúde na mortalidade por todas as causas.

Resultados. Idade maior de 60 anos, admissão em hospital com serviço de emergência, coinfecção HIV / TB e reingresso a um serviço ambulatorial após recorrência da TB ou perda de seguimento foram identificados como fatores de risco para a morte. Variáveis de processo e indicadores de resultados do Programa Nacional de Controle da Tuberculose não guardaram relação com a mortalidade por todas as causas.

Conclusões. Idade avançada, tratamento prévio da TB e tratamento em unidade ambulatorial de nível secundário ou em hospital com serviço de emergência no local apresentaram associação com mortalidade em pacientes com TB. São necessárias estratégias melhores para aprimorar a atenção à TB ofertada nas unidades de saúde, principalmente para idosos.

Registro médico coordenado; mortalidade; análise de sobrevida; tuberculose; serviços de saúde; Brasil. 